\title{
Tolerable amounts of amino acids for human supplementation: summary and lessons from published peer-reviewed studies
}

\author{
François Blachier $^{1}$ (D) Anne Blais ${ }^{1} \cdot$ Rajavel Elango $^{2} \cdot$ Kuniaki Saito $^{3} \cdot$ Yoshiharu Shimomura $^{4} \cdot$ Motoni Kadowaki $^{5}$. \\ Hideki Matsumoto ${ }^{6}$
}

Received: 25 February 2021 / Accepted: 21 July 2021 / Published online: 2 August 2021

(c) The Author(s) 2021

\begin{abstract}
Amino acid supplementation may be indicated to correct for insufficient amino acid intake in healthy individuals, and in specific physiological or pathophysiological situations. However, there is a concern to not supplement beyond the tolerable upper intake level (UL) by determining parameters of no-observed-adverse-effect level (NOAEL) or lowest-observedadverse-effect level (LOAEL) for each amino acid. Since the NOAEL and LOAEL values are at least one order of magnitude different when comparing the values obtained in rats and humans, the aim of this review is to evaluate to what extent the amino acid UL measured in the rat model, when referenced to the dietary usual consumption (UC) and dietary requirement (RQ) for indispensable amino acids, may be used as an approximation of the UL in humans. This review then compares the ratios of the NOAEL or LOAEL over UC and RQ in the rat model with the same ratios calculated in humans for the nine amino acids (arginine, serine, glycine, histidine, leucine, lysine, methionine, phenylalanine, and tryptophan) for which this comparison can be done. From the calculations made, it appears that for these 9 amino acids, the calculated ratios for rats and humans, although rather different for several amino acids, remains for all of them in the same order of magnitude. For tryptophan, tyrosine, and valine, the ratios calculated in rats are markedly different according to the sex of animals, raising the view that it may be also the case in humans.
\end{abstract}

Keywords Amino acids $\cdot$ Supplementation $\cdot$ Tolerable upper intake level $\cdot$ Rat model $\cdot$ Humans

Handling editor: $\mathrm{G}$. Wu.

François Blachier

francois.blachier@agroparistech.fr

1 Université Paris-Saclay, AgroParisTech, INRAE, UMR PNCA, Paris, France

2 Department of Pediatrics, School of Population and Public Health, British Columbia Children's Hospital Research Institute, British Columbia Children's Hospital, University of British Columbia, Vancouver, Canada

3 School of Medical Sciences, Fujita Health University, Toyoake, Aichi, Japan

4 College of Bioscience and Biotechnology, Chubu University, Kasugai, Aichi, Japan

5 Niigata Institute of Technology, Niigata, Japan

6 International Council on Amino Acid Science of Japan, Tokyo, Japan

\section{Introduction}

Amino acid supplementation may be indicated in healthy individuals to correct for deficiency of one or several amino acids in the dietary protein consumed by humans. Amino acid supplementation may also be indicated in specific physiological or pathophysiological situations. Clinical and experimental studies have shown for instance that supplementation with specific amino acids or their metabolites may contribute to limit muscle wasting in vulnerable patient groups (Martinez-Arnau et al. 2020; Wandrag et al. 2015); and supplementation with specific amino acids in rats with chemically induced colitis has been shown to favorably accelerate the process of intestinal mucosal healing after an episode of mucosal inflammation (Liu et al. 2013).

Adequate intake of amino acids from dietary protein can be defined as the need, in appropriate amounts, of all amino acids required for protein synthesis/renewal and for utilization of amino acids in other metabolic pathways. Alternate pathways include energy production and synthesis of various 
compounds with biological activities in terms of metabolism and physiological functions. The need for these latter compounds represents generally a minor proportion of the amino acid utilization. However, this is not always the case. Glutathione synthesis, for instance, has been reported to represent a relatively large part of cysteine utilization in the body during infection and intestinal inflammation (Malmezat et al. 2000; Rémond et al. 2011). Among the 20 amino acids present in dietary proteins, 9 of them (isoleucine, leucine, valine, lysine, methionine, phenylalanine, threonine, tryptophan, and histidine) are considered as indispensable as they have to be provided in the diet to meet the body's requirement (Gietzen and Rogers 2006). From a metabolic point of view, among the 9 indispensable amino acids, 2 amino acids (lysine and threonine) are considered as strictly indispensable, as they cannot be synthesized by the body, notably by reamination of their corresponding ketoacids (Reeds 2000). Among the 11 other amino acids, six of them (arginine, cysteine, proline, tyrosine, glutamine, and glycine) are classified as conditionally indispensable, because their biosynthesis capacity in the body may be insufficient compared to the requirement in specific physiological and pathophysiological situations (Fürst and Stehle 2004). For indispensable amino acids, the requirements have been estimated in humans, and, as performed in this review, these requirements can be usefully compared with the mean usual consumption from the diet and supplements referred as consumption from all sources.

There is a major concern to not supplement beyond the amino acid tolerable upper intake level (UL) by determining parameters including the no-observed-adverse-effect level (NOAEL) and the lowest-observed-adverse-effect level (LOAEL) for each amino acid. NOAEL, commonly defined as the highest experimental intake that is without measurable adverse effect, does not fully address the interpretation of risk based on toxicologically relevant effects, nor does it consider the progression of effects with respect to duration and/or dose (Dorato and Engelhardt 2005). The tolerable UL can be defined as the highest level of daily nutrient intake that is likely to pose no risks of adverse effects in healthy individuals in the general population (Kennedy and Meyers 2005; Pizzo and Benfenati 2016). The 2005 Food and Nutrition Board, Institute of Medicine (FNB/IOM) reports dietary reference intakes (DRI) for energy, carbohydrate, fiber, fat, fatty acids, cholesterol, protein, and amino acids, and recommends that UL should be preferentially related to the NOAEL values when available. Although the difficulty of this task should not be under-estimated, data obtained from experiments with animals, and from few clinical studies are helpful in an attempt to define such amino acid ULs, and to fix an upper limit of what can be safely consumed. The determination of such safe limits for each amino acid is dependent on the identification of relevant biological end-points. In humans, for obvious ethical reasons, there is a limitation of the parameters that can be measured, compared to animal models. By summarizing the data obtained from studies in animal models and clinical studies in volunteers, a large heterogeneity of experimental design appears regarding notably supplementation duration (short-, middle-, and long-term experiments), parameters measured, dietary context, and age and sex of individuals. From another point of view, based on the guiding principles for ethical use of laboratory animals for research, namely replacement, reduction and refinement (Baumans 2005), we consider that, due to a relatively large number of peer-reviewed rodent toxicological studies with amino acids, it is desirable to try to interpret these data in term of amino acid safety in human. In that way, we hope to stimulate both new clinically relevant analyses and to reduce future experiments with rodents.

Since the NOAEL and LOAEL values determined for some amino acids are different by at least one order of magnitude when comparing the values determined in rats and humans, the overall aim of this review is to evaluate to what extent the UL determined for some amino acids from the NOAEL and LOAEL measured in animal models in healthy situation are informative when compared to the amino acid supply in standard feed/diet, reported to the Usual Consumption (UC) and requirement (RQ) for tentative extrapolation from rats to humans, notably for the amino acids for which no UL have been proposed for humans. UC has been defined in volunteers in reference to the dietary consumption over 1 year, ideally on each day of the year, keeping in mind that the self-reported nature of the data may lead to bias compared to the true consumption (Illner et al. 2010). Food frequency questionnaire is often used to evaluate UC (Siddiqui et al. 2019). Indispensable amino acid requirements (RQ) have been determined as $\mathrm{mg} / \mathrm{kg} \mathrm{BW} /$ day in growing rats (Benevenga et al 1994) and humans. Since most of the experiments with animal models have been done using the rat model, we have focused on the data obtained with this animal model, and when possible, we have also taken into account the biological sex effect. This does not mean that other animal models, like the pig model, are not relevant for human extrapolation (Chalvon-Demersay et al. 2017). However, regarding the pig model, only few data are available regarding the determination of the upper safe limit for amino acid intake in supplements.

\section{Indispensable amino acids}

\section{Histidine UL}

L-histidine is incorporated into proteins and metabolized leading to the production of glutamate. Histidine is a component of the dipeptide carnosine, a compound notably 
involved in pH-buffering. In addition, this amino acid displays metal-ion chelation, antioxidant actions (Boldyrev et al. 2013), and anti-inflammatory effects (Andou et al. 2009). Finally, histidine is the precursor of the biogenic amine histamine.

In rats, the amount of histidine in the standard diet is $3.3 \mathrm{~g}$ histidine/kg diet (Reeves et al. 1993). If we consider that laboratory rats on standard normoproteic diet eat approximately $22 \mathrm{~g}$ food per day (Liu et al. 2014), this will represent $72.6 \mathrm{mg}$ histidine per day, and thus, based on a rat body weight (BW) that is usually approximately $250 \mathrm{~g}$ at the time of biological parameter determination, we can calculate an UC equal to $290.4 \mathrm{mg}$ histidine/kg BW/day (Table 1). The NOAEL for histidine, as determined using parameters of subchronic toxicity, is, respectively, for male and female rats 1631 and $1757 \mathrm{mg} / \mathrm{kg} \mathrm{BW/day,} \mathrm{while} \mathrm{the} \mathrm{LOAEL} \mathrm{is}$ 3481 and $3592 \mathrm{mg} / \mathrm{kg} \mathrm{BW} /$ day, respectively (Ikesaki et al. 1994). The NOAEL/UC ratios for male and female are thus 5.6 and 6.1, respectively. The LOAEL/UC ratios for male and female are 12.0 and 12.4, respectively (Table 1). Amount of each amino acid RQ is calculated with reported amino acid requirements for growth in rats (Benevenga et al. 1994). In this animal model, histidine RQ is $133.3 \mathrm{mg} / \mathrm{kg} /$ day (Table 2), thus below the UC. The NOAEL/RQ ratios for male and female are 12.2 and 13.2, respectively, while the LOAEL/RQ ratios for male and female are 26.1 and 26.9, respectively.

In humans, the daily requirement for histidine is $11.0 \mathrm{mg} /$ $\mathrm{kg} \mathrm{BW/day} \mathrm{(Table} \mathrm{2),} \mathrm{while} \mathrm{the} \mathrm{consumption} \mathrm{from} \mathrm{dietary}$ sources and supplements (thus UC from all sources) average $2.20 \mathrm{~g} /$ day (FNB/IOM 2005), thus representing $31.43 \mathrm{mg} /$ $\mathrm{kg}$ BW/day (Table 1). When volunteers were given histidine supplementation for 4 weeks, and when parameters including anthropometric analysis, determination of body composition, sleep patterns, dietary intake, and urine analysis were performed, no deleterious effects of histidine given as supplement up to $8 \mathrm{~g} /$ day were observed, this NOAEL value is corresponding to $91.2 \mathrm{mg} / \mathrm{kg} \mathrm{BW} /$ day (Gheller et al. 2020) (Table 1). The NOAEL/UC ratio is 2.9 , a value close to the one found in rats. As indicated in Table 1, the LOAEL for histidine has been determined to be $134.1 \mathrm{mg} / \mathrm{kg} \mathrm{BW} /$ day (Gheller et al. 2020). The LOAEL/UC ratio is 4.3 (Table 1). The NOAEL/RQ and LOAEL/RQ ratios are 8.3 and 12.2, respectively (Table 2 ).

Then, for histidine, the NOAEL/UC ratios are not vastly different when comparing the data obtained in rats and humans, being equal to 5.8 and 2.9, respectively. However, for histidine, the LOAEL/UC ratios are much more different when comparing rats and humans, being equal to 12.2 and 4.3 , respectively. The NOAEL/RQ ratios for histidine are not very different when comparing the data obtained in rats and humans, being equal to 12.7 and 8.3 , respectively. The LOAEL/RQ ratios are rather different, but within the same order of magnitude, when comparing the data obtained in rats and humans, being equal to 26.5 and 12.2, respectively.

\section{Isoleucine UL}

L-isoleucine, together with L-leucine and L-valine, are branched-chain amino acids. The branched-chain amino acids, in addition to being required for protein synthesis, can be transaminated in the presence of $\alpha$-ketoglutarate allowing production of glutamate and the corresponding $\alpha$-ketoacid (Duan et al. 2016). Each $\alpha$-ketoacid can then undergo oxidative decarboxylation (Matsumoto et al. 2010, 2014). The products of decarboxylation can then undergo several steps of conversion allowing the synthesis of acetyl-CoA, acetoacetic acid, and succinyl-CoA.

In rats, the amount of isoleucine in standard diet is $5.9 \mathrm{~g} /$ $\mathrm{kg}$ diet (Reeves et al. 1993), and thus, based on the same calculation as used above represents an UC equal to $519.2 \mathrm{mg} /$ $\mathrm{kg} \mathrm{BW} /$ day (Table 1). RQ is $295.2 \mathrm{mg} / \mathrm{kg} / \mathrm{day}$ (Table 2). Based on BW, food consumption, ophthalmic signs, protein and electrolytes in urine, hematological parameters, blood biochemistry, and histopathological analysis determined after 13 weeks of isoleucine supplementation, NOAEL of $1565 \mathrm{mg} / \mathrm{kg}$ BW/day in males and $1646 \mathrm{mg} / \mathrm{kg} \mathrm{BW/}$ day in females have been proposed (Tsubuku et al. 2004a) (Table 1). Similarly, the LOAEL for isoleucine has been determined to be 3008 and $3702 \mathrm{mg} / \mathrm{kg} \mathrm{BW} /$ day for male and female rats, respectively (Tsubuku et al. 2004a). The NOAEL/UC ratios for isoleucine are then equal to 3.0 and 3.2 for male and female rats, respectively. The LOAEL/ $\mathrm{UC}$ ratios are equal to 5.8 and 7.1 for male and female rats, respectively (Table 1 ). The NOAEL/RQ ratios for male and female are 5.3 and 5.6, respectively. The LOAEL/RQ ratios for male and female are 10.2 and 12.5 , respectively (Table 2). The calculated ratios for male and female are thus similar.

In humans, the daily isoleucine requirement is $15.0 \mathrm{mg} /$ $\mathrm{kg} \mathrm{BW/day} \mathrm{(Table} \mathrm{2),} \mathrm{while} \mathrm{the} \mathrm{mean} \mathrm{UC} \mathrm{from} \mathrm{all} \mathrm{sources}$ is $3.55 \mathrm{~g} /$ day (FNB/IOM 2005) thus representing $50.71 \mathrm{mg} /$ $\mathrm{kg} \mathrm{BW/day} \mathrm{(Table} \mathrm{1),} \mathrm{a} \mathrm{value} \mathrm{largely} \mathrm{above} \mathrm{the} \mathrm{requirement.}$ No NOAEL or LOAEL have been determined in humans.

\section{Leucine UL}

In rats, the amount of L-leucine in standard diet is $10.9 \mathrm{~g} / \mathrm{kg}$ diet (Reeves et al. 1993), and thus represents an UC equal to $959.2 \mathrm{mg} / \mathrm{kg} \mathrm{BW} /$ day. RQ is $509.5 \mathrm{mg} / \mathrm{kg} /$ day (Table 2). In female rats during gestation, supplementation of the diet for 11 weeks with an aqueous solution of leucine equal to $1000 \mathrm{mg} / \mathrm{kg} \mathrm{BW} /$ day had little impact on BW, food intake, litter size, weight, and fetus characteristics (Mawatari et al. 2004). After consumption for 13 weeks of diet supplemented with increasing amounts of leucine, and based on parameters 


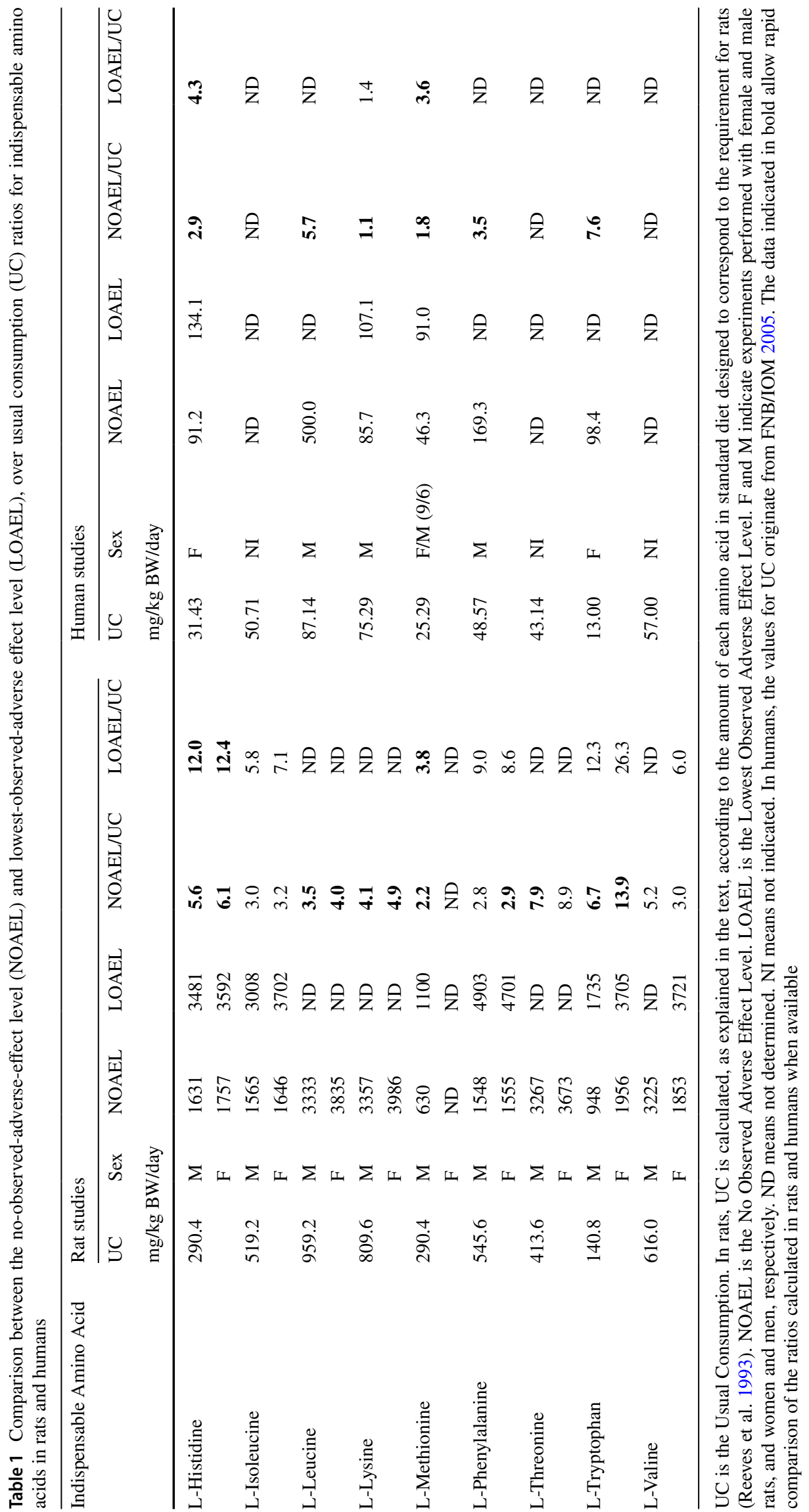




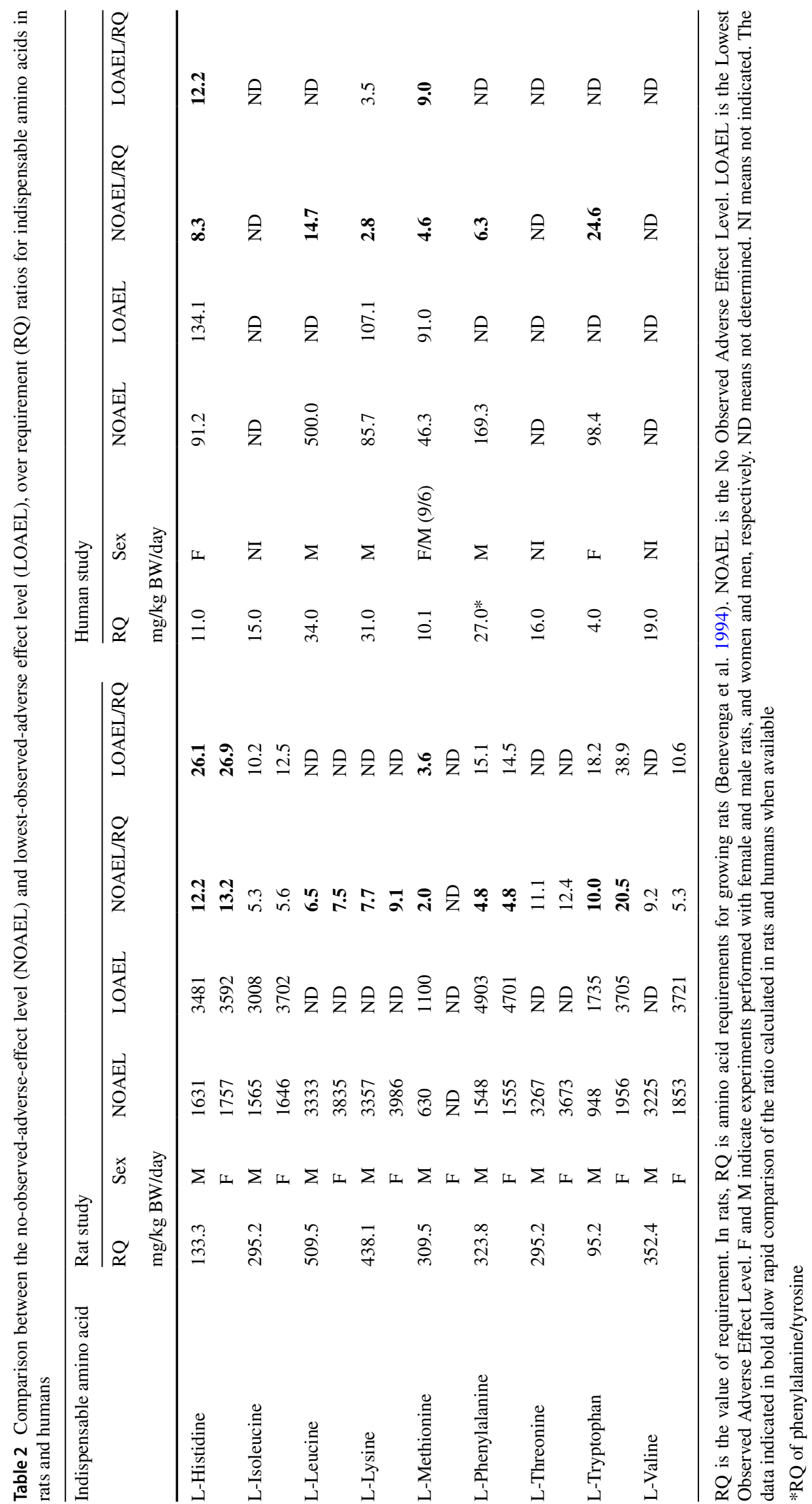


including BW, food consumption, organ weight, hematological parameters and blood biochemistry, the NOAEL for leucine was determined to be $3333 \mathrm{mg} / \mathrm{kg} \mathrm{BW} /$ day for males and $3835 \mathrm{mg} / \mathrm{kg} \mathrm{BW} /$ day for females (Tsubuku et al. 2004a). Thus, the NOAEL/UC ratios are equal to 3.5 and 4.0 for male and female rats, respectively (Table 1). The NOAEL/ RQ ratios are equal to 6.5 and 7.5 for male and female rats, respectively (Table 2). Then, the calculated NOAEL/UC ratio for rats, whatever their sex, is equal to approximately 3.7. Similarly, the NOAEL/RQ ratios for male and female, whatever their sex, are equal to 7.0.

In humans, as indicated in Table 2, the estimated daily requirement of leucine is $34.0 \mathrm{mg} / \mathrm{kg} \mathrm{BW} /$ day (FNB/IOM 2005). The mean amount of leucine provided from all sources is $6.10 \mathrm{~g} /$ day (FNB/IOM 2005), corresponding to an UC equal to $87.14 \mathrm{mg} / \mathrm{kg} \mathrm{BW} /$ day (Table 1). This value is here again above the requirement. In adult men, based on parameters that include the upper maximal capacity to oxidize leucine, as well as concentrations of glucose, insulin, alanine aminotransferase, and ammonia in blood, it was found that leucine supplementation at doses above $550 \mathrm{mg} /$ $\mathrm{kg} \mathrm{BW} /$ day (39 g for a $70 \mathrm{~kg} \mathrm{BW}$ volunteers), when given acutely, may be above the upper safe limit (Pencharz et al. 2012). In elderly men, the upper limit for leucine supplementation is similar to the value found in young men (Elango et al. 2016). The proposed total dietary leucine upper limit of safe intake for the elderly is $500.0 \mathrm{mg} / \mathrm{kg} \mathrm{BW} /$ day (Cynober et al. 2016). This value represents 5.7-fold the UC (Table 1), a value not vastly different from the one calculated in rats. Based on the RQ equal to $34.0 \mathrm{mg} / \mathrm{kg} / \mathrm{day}$, the NOAEL/RQ ratio is 14.7 (Table 2).

Then, for leucine, the NOAEL/UC ratio is equal to 3.7 in rats, while in humans, the ratio is equal to 5.7. Thus, the ratios calculated for leucine are not vastly different between rats and humans. However, the NOAEL/RQ ratios average 7.0 and 14.7 for rats and humans respectively.

\section{Lysine UL}

L-lysine, in addition to being incorporated into proteins, is a precursor of acetoacetyl-CoA, carnitine, and of the polyamine cadaverine.

In rats, the standard diet contains $9.2 \mathrm{~g}$ lysine $/ \mathrm{kg}$ diet (Reeves et al. 1993), thus representing an UC equal to $809.6 \mathrm{mg} / \mathrm{kg} \mathrm{BW} /$ day (Table 1). RQ is $438.1 \mathrm{mg} / \mathrm{kg} /$ day (Table 2). Supplementation with lysine in the diet given ad libitum at increasing doses for 13 weeks was performed in rats, and parameters including $\mathrm{BW}$, diet consumption, water intake, ophthalmic signs, organ weights, renal function, and histological examination were used to determine the NOAEL for lysine. NOAEL for this amino acid was found to be $3357 \mathrm{mg} / \mathrm{kg} \mathrm{BW} /$ day in male rats, and the value for females was $3986 \mathrm{mg} / \mathrm{kg}$ BW/day (Tsubuku et al. 2004b).
The NOAEL/UC ratios are then 4.1 and 4.9 for male and female rats, respectively (Table 1 ). The NOAEL/RQ ratios for male and female are 7.7 and 9.1, respectively (Table 2). The NOAEL/UC and NOAEL/RQ ratios averaged 4.5 and 8.4, respectively, for rats whatever their sex.

In humans, as indicated in Table 2, the estimated daily $\mathrm{RQ}$ for leucine is $31.0 \mathrm{mg} / \mathrm{kg} \mathrm{BW} /$ day (FNB/IOM 2005). The mean amount of lysine provided from all sources is $5.27 \mathrm{~g} /$ day (FNB/IOM 2005; Martin et al. 2004), and thus, the UC is $75.29 \mathrm{mg} / \mathrm{kg} \mathrm{BW} /$ day (Table 1), a value markedly above the requirement. Supplementation with lysine can cause symptoms related to the gastrointestinal tract such as nausea, stomach ache, and diarrhea. These results led to propose a provisional NOAEL equal to $6000 \mathrm{mg} /$ person/day (Hayamizu et al. 2019), thus corresponding to $85.7 \mathrm{mg} / \mathrm{kg}$ BW/day for an individual weighing $70 \mathrm{~kg}$, while an LOAEL equal to $107.1 \mathrm{mg} / \mathrm{kg}$ BW/day has been determined (Hayamizu et al. 2019). Thus, the NOAEL and LOAEL/UC ratios are 1.1 and 1.4, respectively (Table 1). The NOAEL/RQ and LOAEL/RQ ratios are 2.8 and 3.5 (Table 2).

Thus, in the case of lysine, the NOAEL/UC ratio is much higher in rats (i.e., being equal to 4.5) than in humans (i.e., 1.1). The ratio of NOAEL/RQ for lysine is also higher for rats than for humans being equal to 8.4 and 2.8 , respectively. In humans, the dose of lysine with no adverse effect is close to the UC.

\section{Methionine UL}

L-methionine is considered one of the most deleterious amino acid when given in excess (Harper et al. 1970). Methionine metabolism in tissues, which is rather complex, is related to the synthesis of numerous compounds with biological activities. L-methionine, in addition to serving as a precursor for protein synthesis, is a substrate together with L-lysine for carnitine synthesis, a compound involved in the metabolism of fatty acids (Longo et al. 2016). Methionine can be converted in three steps into homocysteine. Importantly, S-adenosylmethionine that is produced at the first step is a methyl donor involved in more than 60 methylation reactions in the body including phosphatidylcholine and DNA synthesis, as well as histone methylation (Brosnan and Brosnan 2006). These two latter methylation processes represent an important component for the regulation of gene expression in cells (Etchegaray and Mostoslavsky 2016). Then, homocysteine can be converted back to methionine in the pathways involving vitamin $\mathrm{B}_{12}$, 5-methyl tetrahydrofolate (5-methyl THF) and betaine, or be converted to cysteine in a vitamin $\mathrm{B}_{6}$-dependent pathway. Cysteine is the precursor, together with glutamate and glycine, of the tripeptide glutathione (GSH) that is involved in the control of the intracellular redox status and of the intracellular concentrations of reactive oxygen and reactive nitrogen species 
(Kemp et al. 2008; Chakravarthi et al. 2006). Cysteine is also the precursor of taurine, a compound notably involved in bile acid conjugation after bile acid synthesis from cholesterol (Chen et al. 2012). Last but not least, cysteine by itself, or in conjunction with homocysteine, is a precursor for the synthesis of hydrogen sulfide $\left(\mathrm{H}_{2} \mathrm{~S}\right)$ (Blachier et al. 2019). Hyperhomocysteinemia, that can be observed in volunteers after supplementation with methionine (Chao et al. 2000), has been associated with increased risk for atherosclerotic and atherothrombotic vascular diseases (Zylberstein et al. 2004). However, the causal link between hyperhomocysteinemia and risk of atherosclerotic disease remains controversial (Blachier et al. 2020). Indeed, it appears that lowering homocysteinemia by itself is not sufficient for decreasing the risk of cardiovascular disease progression in volunteers (Ebbing et al. 2008), and that reduced synthesis of other compounds related to methionine and cysteine metabolism, like phosphatidylcholine and hydrogen sulfide, is also presumably detrimental when considering the risk of atherosclerosis (van der Veen 2017; Mani et al. 2013).

In rats, the amount of methionine in standard diet is $3.3 \mathrm{~g} /$ $\mathrm{kg}$ diet (Reeves et al. 1993), thus representing an UC equal to $290.4 \mathrm{mg} / \mathrm{kg} \mathrm{BW/day} \mathrm{(Table} \mathrm{1).} \mathrm{RQ} \mathrm{for} \mathrm{methionine} \mathrm{is}$ $309.5 \mathrm{mg} / \mathrm{kg} / \mathrm{day}$ (Table 2), thus close to UC. Based on parameters including food intake, body weight, white blood cell count, thymus atrophy, and histological abnormalities in the adrenal gland and testis, the NOAEL found for methionine added to the diet of male rats for 4 weeks is $630 \mathrm{mg} /$ $\mathrm{kg} \mathrm{BW/day,} \mathrm{thus} \mathrm{not} \mathrm{vastly} \mathrm{different} \mathrm{from} \mathrm{the} \mathrm{UC,} \mathrm{while} \mathrm{the}$ LOAEL is $1100 \mathrm{mg} / \mathrm{kg} \mathrm{BW/day} \mathrm{(Chin} \mathrm{et} \mathrm{al.} \mathrm{2015).} \mathrm{Thus,}$ the NOAEL for methionine in supplement/UC ratio is 2.2 , and LOAEL for methionine in supplement/UC ratio can be approximated to 3.8 in rats (Table 1). Since RQ for methionine is $309.5 \mathrm{mg} / \mathrm{kg} / \mathrm{day}$, then the NOAEL/RQ and LOAEL/ RQ ratios are 2.0 and 3.6, respectively (Table 2).

In humans, the estimated RQ for methionine plus cysteine is $15.0 \mathrm{mg} / \mathrm{kg} \mathrm{BW/day} \mathrm{(FNB/IOM} \mathrm{2005),} \mathrm{while} \mathrm{the} \mathrm{RQ} \mathrm{for}$ methionine in the presence of an excess of dietary cysteine is $10.1 \mathrm{mg} / \mathrm{kg} \mathrm{BW} /$ day (Di Buono et al. 2001). The amount of methionine provided by all sources (UC) is approximately $1.77 \mathrm{~g} /$ day (FNB/IOM 2005; Martin et al. 2004), thus representing an UC equal to $25.29 \mathrm{mg} / \mathrm{kg} \mathrm{BW} /$ day for an individual weighing $70 \mathrm{~kg}$, a value above the requirement. Based on plasma homocysteine as the primary determinant, but also on numerous other biochemical blood variables, as well as on answers to questionnaires regarding quality of life and cognitive function, the NOAEL for methionine is $46.3 \mathrm{mg} /$ $\mathrm{kg} \mathrm{BW} /$ day, while the LOAEL is $91.0 \mathrm{mg} / \mathrm{kg} \mathrm{BW} /$ day (Deutz et al. 2017). Thus, the NOAEL for methionine/UC ratio is 1.8 , and LOAEL/UC ratio is 3.6, these ratios being not vastly different from the ratios determined in rats (Table 1). Considering the RQ for methionine in the presence of an excess of cysteine, the NOAEL/RQ and LOAEL/RQ ratios are 4.6 and 9.0, respectively (Table 2).

Then, regarding methionine, which is considered as one of the most deleterious amino acid when consumed in excess, we have calculated from the available data that both the LOAEL/UC and the NOAEL/UC ratios are close in rats and humans, while the NOAEL/RQ and the LOAEL/RQ ratios are higher for humans than for rats.

\section{Phenylalanine UL}

L-phenylalanine is incorporated into proteins and is a precursor of tyrosine and acetoacetyl-CoA.

In rats, the amount of phenylalanine in standard diet is $6.2 \mathrm{~g} / \mathrm{kg}$ diet (Reeves et al. 1993), thus representing an UC equal to $545.6 \mathrm{mg} / \mathrm{kg}$ BW/day (Table 1). RQ is $323.8 \mathrm{mg} / \mathrm{kg} /$ day (Table 2). Based on the parameters including BW and food consumption measurement, organ weight, ophthalmic observation, red blood cell count, and blood glucose concentration measured after 4 weeks of ad libitum consumption of diet supplemented with phenylalanine, the authors proposed an NOAEL equal to $1.5 \%(\mathrm{w} / \mathrm{w})$ for this amino acid (Shibui et al. 2014). The NOAEL for phenylalanine then represents 1548 and $1555 \mathrm{mg} / \mathrm{kg} \mathrm{BW/day} \mathrm{in} \mathrm{male} \mathrm{and} \mathrm{female}$ rats, respectively (Shibui et al. 2014), and the LOAEL represents, respectively, 4903 and $4701 \mathrm{mg} / \mathrm{kg} \mathrm{BW/day} \mathrm{(Shibui}$ et al. 2014). Thus, the NOAEL/UC ratios are 2.8 and 2.9 for male and female rats, respectively. The ratio of LOAEL over UC is 9.0 and 8.6 for male and female rats, respectively (Table 1). The NOAEL/RQ ratios for male and female rats are both equal to 4.8 . The LOAEL/RQ ratios for male and female are 15.1 and 14.5 , respectively (Table 2 ).

In humans, the RQ for aromatic amino acids (phenylalanine/tyrosine) is $27.0 \mathrm{mg} / \mathrm{kg} \mathrm{BW} /$ day (Table 2), and the mean intake of phenylalanine from all sources is $3.40 \mathrm{~g} / \mathrm{day}$ (FNB/IOM 2005), and thus corresponds to an UC equal to $48.57 \mathrm{mg} / \mathrm{kg} \mathrm{BW} /$ day (Table 1). The NOAEL for phenylalanine is $169.3 \mathrm{mg} / \mathrm{kg} \mathrm{BW} /$ day (Miura et al. 2021). Thus, the NOAEL/UC ratio is 3.5 , these ratios being close to the ratios determined in rats (Table 1). The NOAEL/RQ is 6.3 for humans (Table 2).

\section{Threonine UL}

L-threonine is used for protein synthesis and for the synthesis of glycine and acetyl-CoA. Threonine is abundant in some proteins, such as intestinal mucins, that protect the intestinal epithelium against the deleterious effects of some compounds present in the intestinal luminal content (Munasinghe et al. 2017). The amount of threonine in standard diet for rats is $4.7 \mathrm{~g} / \mathrm{kg}$ diet (Reeves et al. 1993), and thus represents an UC equal to $413.6 \mathrm{mg} / \mathrm{kg} \mathrm{BW/day} \mathrm{(Table} \mathrm{1).} \mathrm{RQ} \mathrm{is}$ $295.2 \mathrm{mg} / \mathrm{kg} /$ day (Table 2). By measuring parameters like 
BW, food consumption, food efficiency, ophthalmic signs, hematological and blood biomarkers after 13 week supplementation with threonine, the NOAEL for this amino acid was determined to be 3267 and $3673 \mathrm{mg} / \mathrm{kg} \mathrm{BW} /$ day in male and female rats, respectively (Aoki et al. 2014 ${ }^{\mathrm{a}}$ ). The NOAEL/UC ratios are 7.9 and 8.9 for male and female rats, respectively (Table 1 ). The NOAEL/RQ ratios for male and female are 11.1 and 12.4 , respectively (Table 2 ).

In humans, the threonine requirement has been estimated to be $16.0 \mathrm{mg} / \mathrm{kg} \mathrm{BW} /$ day (Table 2), and the mean amount of threonine from all sources is $3.02 \mathrm{~g} /$ day (FNB/IOM 2005), that corresponds to an UC equal to $43.14 \mathrm{mg} / \mathrm{kg} \mathrm{BW} /$ day (Table 1). No NOAEL or LOAEL has been determined in humans.

\section{Tryptophan UL}

L-tryptophan, in addition to its precursor role for protein synthesis, is also a precursor for numerous compounds with biological activities, like the neurotransmitters serotonin and tryptamine, the hormone melatonin, and the vitamin-like compounds niacin and nicotinic acid (Kaluzna-Czaplinska et al. 2019). Tryptophan catabolism also leads to the synthesis of kynurenine, which controls several neurotransmitter systems (Schwarcz and Stone 2017). Moreover, tryptophan is a precursor for acetyl-CoA synthesis.

In rats, the amount of tryptophan in standard diet is $1.6 \mathrm{~g} /$ $\mathrm{kg}$ diet (Reeves et al. 1993), and thus represents an UC equal to $140.8 \mathrm{mg} / \mathrm{kg} \mathrm{BW} /$ day (Table 1). RQ is equal to $95.2 \mathrm{mg} /$ $\mathrm{kg} \mathrm{BW/day} \mathrm{(Table} \mathrm{2).} \mathrm{Based} \mathrm{on} \mathrm{BW} \mathrm{and} \mathrm{food} \mathrm{consumption}$ as well as other parameters including organ weight, histopathological analysis, and blood glucose measured after 13 weeks supplementation, the NOAEL for the tryptophan is $948 \mathrm{mg} / \mathrm{kg} \mathrm{BW} /$ day in males and $1956 \mathrm{mg} / \mathrm{kg} \mathrm{BW} /$ day in females. The LOAEL is 1735 and $3705 \mathrm{mg} / \mathrm{kg}$ BW/day for male and female rats, respectively (Shibui et al. 2018). Thus, the NOAEL/UC ratios in male and female rats are 6.7 and 13.9, respectively. The LOAEL/UC ratios in male and female are 12.3 and 26.3, respectively (Table 1). The NOAEL/RQ ratios for male and female are 10.0 and 20.5, respectively. The LOAEL/RQ ratios for male and female are 18.2 and 38.9, respectively (Table 2). The reasons for such huge difference for NOAEL and LOAEL between male and female rats are not known, but may rely on differences in tryptophan metabolism according to the animal sex. Measurement of maximal tryptophan oxidation rate in males and females may represent a way to measure the intake above which risk of adverse effects appear (Moehn et al. 2012).

In humans, the tryptophan requirement is $4.0 \mathrm{mg} / \mathrm{kg}$ BW/day (FNB/IOB 2005) (Table 2). The mean amount of tryptophan provided from all sources is $0.91 \mathrm{~g} /$ day $(\mathrm{FNB} /$ IOM 2005), thus representing an UC equal to $13.0 \mathrm{mg} / \mathrm{kg}$ $\mathrm{BW} /$ day, a value greatly above the requirement (Table 1 ). In healthy adult women, based on parameters like food intake, BW, blood and urine biomarkers, amino acid concentration in blood and urine, and profile of mood states category, the dose of $5.0 \mathrm{~g} / \mathrm{day}$ of tryptophan (thus $98.4 \mathrm{mg} / \mathrm{kg} \mathrm{BW} /$ day) used in supplement for 3 weeks showed no adverse effects (Hiratsuka et al. 2013). Thus, the NOAEL/UC ratio in humans can be calculated to be 7.6, a value relatively close to the NOAEL/UC ratio found in male rats, but lower than the ratio calculated for female rats (Table 1). On another hand, the NOAEL/RQ ratio for women is 24.6, a value relatively close to the value of NOAEL/RQ ratio found in female rats (Table 2).

\section{Valine UL}

In rats, the amount of valine in standard diet is $7.0 \mathrm{~g} / \mathrm{kg}$ diet (Reeves et al. 1993), thus representing an UC equal to $616.0 \mathrm{mg} / \mathrm{kg} \mathrm{BW} /$ day (Table 1). RQ is $352.4 \mathrm{mg} / \mathrm{kg} \mathrm{BW} /$ day (Table 2). After 13 weeks of valine supplementation, measurement of different parameters including BW, dietary consumption, ophthalmic signs, urine analysis, hematological and blood biochemical analysis, organ weight, and histopathological observation, allowed to propose an NOAEL for valine equal to $3225 \mathrm{mg} / \mathrm{kg} \mathrm{BW} /$ day for males, with value for females being $1853 \mathrm{mg} / \mathrm{kg} \mathrm{BW} /$ day. In female rats, the LOAEL has been estimated to be $3721 \mathrm{mg} / \mathrm{kg} \mathrm{BW/}$ day (Tsubuku et al. 2004a). Thus, the NOAEL/UC ratios are 5.2 for males and 3.0 for females. In a similar way, the LOAEL/UC ratio is 6.0 for females (Table 1). The NOAEL/ RQ ratios for male and female are 9.2 and 5.3, respectively. The LOAEL/RQ ratio for female is 10.6 (Table 2).

In humans, the daily requirement for valine is $19.0 \mathrm{mg} / \mathrm{kg}$ BW/day (Table 2), while the consumption from all sources is on average $3.99 \mathrm{~g} / \mathrm{day}$ (FNB/IOM 2005), that corresponds to an UC equal to $57.00 \mathrm{mg} / \mathrm{kg} \mathrm{BW} /$ day (Table 1 ), a value once again markedly above the requirement. No NOAEL or LOAEL has been determined in humans.

\section{Conditionally indispensable and dispensable amino acids}

\section{Alanine UL}

L-alanine, in addition to being used for protein synthesis, is a main substrate for gluconeogenesis. Alanine can be transaminated with $\alpha$-ketoglutarate allowing the synthesis of pyruvate and glutamate.

In rats, the standard diet supplies $3.3 \mathrm{~g}$ alanine $/ \mathrm{kg}$ diet (Reeves et al. 1993), thus representing an UC equal to $290.4 \mathrm{mg} / \mathrm{kg} \mathrm{BW} /$ day (Table 3). Alanine supplementation by gavage for 4 weeks with $2000 \mathrm{mg} / \mathrm{kg} \mathrm{BW} /$ day in rats 
indicated that this dose of alanine is well tolerated by the animals (Aoki et al. 2014b). This conclusion was drawn from the measurement of several parameters including BW, food consumption, ophthalmologic signs, urinary and blood biochemistry, hematological parameters, organ weight, and from histopathological analysis. Then, the NOAEL/UC ratio can be calculated to be equal to 6.9 for both males and females.

In humans, the mean alanine uptake from all sources corresponds to $3.64 \mathrm{~g} / \mathrm{day}$ (thus representing an UC equal to $52.00 \mathrm{mg} / \mathrm{kg} \mathrm{BW} /$ day, FNB/IOM 2005). No NOAEL or LOAEL has been determined in humans.

\section{Arginine UL}

L-arginine, in addition to its role as a precursor for protein synthesis, can be converted to other amino acids present in proteins (notably glutamate, proline) or not present in proteins (ornithine, a precursor for the polyamine synthesis, and citrulline). Arginine is also the precursor for urea, creatine, and nitric oxide (NO). Arginine is used in the hepatic urea cycle for ammonia disposal, while polyamines are involved in cell proliferation, differentiation, and apoptosis, as well as in protein and nucleic acid synthesis and structure (Pegg 2016). Creatine can be phosphorylated into phosphocreatine that is involved in skeletal muscle activity (Strumia et al. 2012). NO regulates numerous physiological functions, notably due to its potent vasodilating effect (Napoli and Ignarro 2009). Arginine is able to stimulate the secretion of numerous hormones including insulin (Blachier et al. 1989) and growth hormone (Andersen 2015).

In rats, the standard diet contains $4.5 \mathrm{~g}$ arginine $/ \mathrm{kg}$ diet (Reeves et al. 1993), and this represents an UC equal to $396.0 \mathrm{mg} / \mathrm{kg} \mathrm{BW}$ (Table 3). Based on parameters including BW, food consumption, organ weight, and histopathological signs, the NOAEL for arginine after 13-week arginine supplementation in rats was found to be $3318 \mathrm{mg} / \mathrm{kg} \mathrm{BW} /$ day in males and $3879 \mathrm{mg} / \mathrm{kg} \mathrm{BW} /$ day in females (Tsubuku et al. 2004c). Thus, the arginine NOAEL/UC ratios in rats are equal to 8.4 for male and 9.8 for female rats (Table 3 ).

In humans, the mean amount of arginine provided by the diet is $4.18 \mathrm{~g} /$ day (FNB/IOM 2005), and thus represents an UC equal to $59.71 \mathrm{mg} / \mathrm{kg} \mathrm{BW}$. In overweight or obese but otherwise healthy volunteers, the measurement of blood pressure, serum concentrations of amino acids, glucose, fatty acids and related metabolites, as well as the measurement of renal, hepatic, and metabolic parameters, indicated that supplementation with L-arginine at a dose of $30 \mathrm{~g} /$ day for 90 days can be considered as safe. The NOAEL for arginine in men and women is, respectively, 277.5 and $304.0 \mathrm{mg} / \mathrm{kg}$ $\mathrm{BW} /$ day (McNeal et al. 2018). Then, the NOAEL/UC ratios is 4.6 and 5.1, respectively for men and women (Table 3). Thus, the NOAEL/UC ratio for human whatever their sex is approximately 4.9. When considering the observed safe level (OSL) of arginine, a somewhat different parameter from the NOAEL and LOAEL, Shao and Hathcock propose to not go beyond an amount of $20 \mathrm{~g}$ arginine per day, thus representing $285.7 \mathrm{mg} / \mathrm{kg} \mathrm{BW} /$ day for $70 \mathrm{~kg} \mathrm{BW}$ individuals (Shao and Hathcock 2008). This value is similar to previous value of NOAEL, i.e., $290.7 \mathrm{mg} / \mathrm{kg}$ BW/day, whatever the biological sex.

Then, for arginine, the NOAEL/UC ratio in rats is equal to 9.1 , while the NOAEL/UC ratio in humans is lower being equal to 4.9 .

\section{Asparagine UL}

L-asparagine is primarily incorporated into the proteins of the body, but is also converted to aspartate and ammonia.

A 90-day toxicity study was performed in male and female rats with increasing amounts of asparagine added to the diet by measuring several parameters including BW, organ weight, blood biochemistry, as well as histological observation (Yokohira et al. 2008). From the data obtained, the authors have proposed an NOAEL for asparagine equal to $1537 \mathrm{mg} / \mathrm{kg} \mathrm{BW} /$ day for males, and $1708 \mathrm{mg} / \mathrm{kg} \mathrm{BW} /$ day for females (Table 3). The LOAEL for asparagine is 3242 and $3466 \mathrm{mg} / \mathrm{kg} \mathrm{BW/day} \mathrm{in} \mathrm{male} \mathrm{and} \mathrm{female} \mathrm{rats,} \mathrm{respec-}$ tively (Yokohira et al. 2008).

In humans, the diet supplies $7.4 \mathrm{~g}$ asparagine per $100 \mathrm{~g}$ alimentary proteins per day (FNB/IOM 2005). Then, based on a usual protein consumption of $85 \mathrm{~g} / \mathrm{day}$, we can estimate an UC for asparagine equal to $89.86 \mathrm{mg} / \mathrm{kg} \mathrm{BW} /$ day. No NOAEL or LOAEL has been determined in humans.

\section{Aspartic acid UL}

L-aspartic acid is used for protein synthesis, but is also transaminated with $\alpha$-ketoglutarate into oxaloacetate and glutamate. Aspartate is used in the urea cycle for the conversion of citrulline into argininosuccinate. Aspartate is a precursor for pyrimidine synthesis. Finally, aspartate is an energy substrate for several cell phenotypes including the intestinal epithelial cells (Windmueller and Spaeth 1976).

In rats, the dietary supply of aspartic acid is $8.0 \mathrm{~g} / \mathrm{kg}$ diet (Reeves et al. 1993), thus representing an UC equal to $704.0 \mathrm{mg} / \mathrm{kg} \mathrm{BW} /$ day (Table 3). In this model, supplementation with increasing amounts of aspartate was performed for 90 days, and parameters including serum and urinary parameters, weight, and histological examination of the kidneys and salivary glands were determined (Tada et al. 2008). From the data obtained, an NOAEL of $697 \mathrm{mg} / \mathrm{kg}$ BW/day is proposed for males, while the proposed value for females is $715 \mathrm{mg} / \mathrm{kg}$ BW/day. The LOAEL for aspartic acid in male and female rats represent 1417 and $1470 \mathrm{mg} / \mathrm{kg}$ BW/day respectively (Tada et al. 2008). Then, the NOAEL/UC ratio 


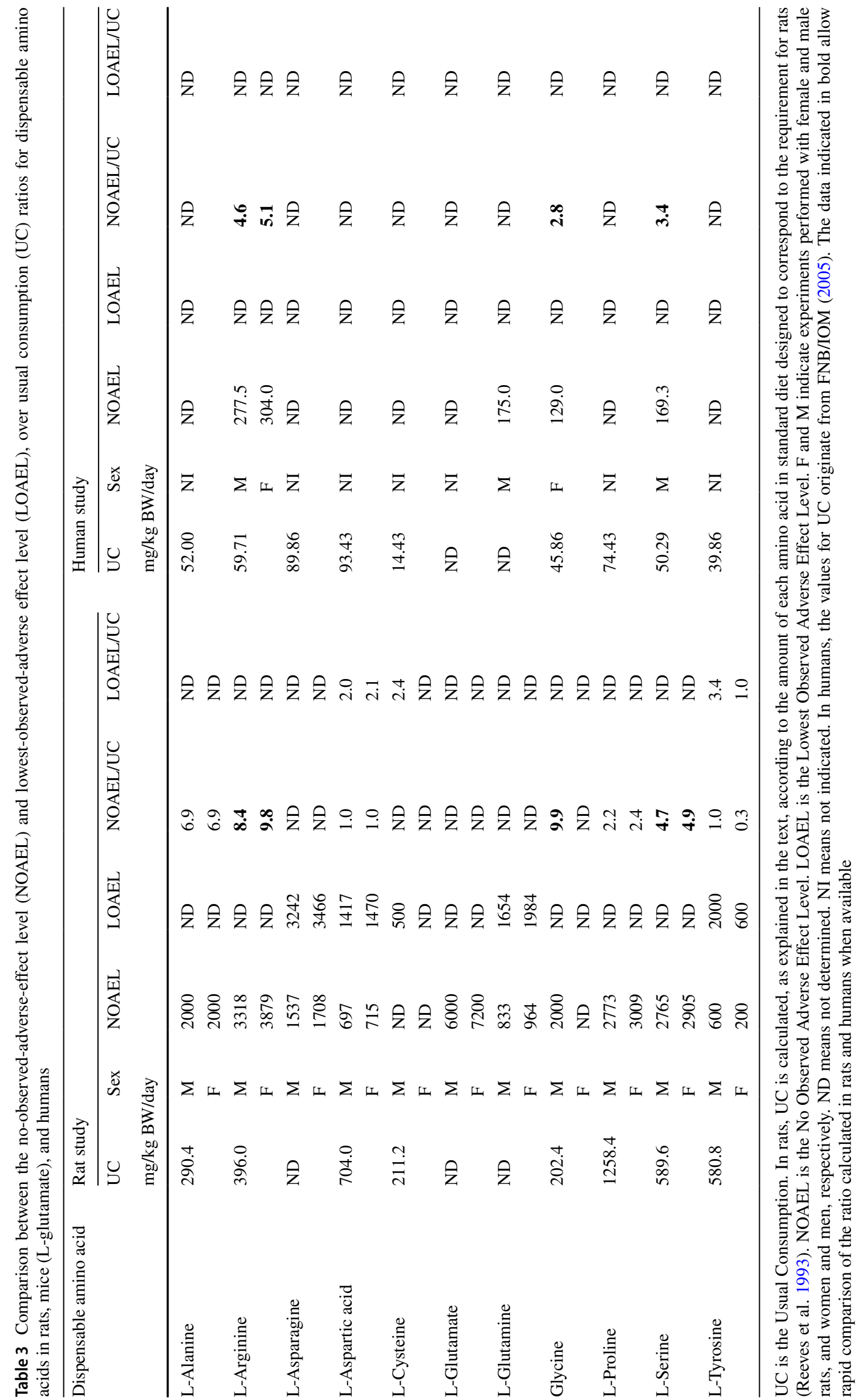


is 1.0 for both male and female rats (Table 3). Thus, from this study, it appears that the NOAEL for aspartate is close to the UC. The LOAEL/UC ratios are 2.0 and 2.1 for male and female rats, respectively (Table 3 ).

In humans, the consumption of aspartic acid from the diet and supplements averages $6.54 \mathrm{~g} /$ day (FNB/IOM 2005), thus representing an $\mathrm{UC}$ equal to $93.43 \mathrm{mg} / \mathrm{kg} \mathrm{BW} /$ day. No NOAEL or LOAEL has been determined in humans.

\section{Cysteine UL}

L-cysteine metabolism is described briefly in the above paragraph concerning methionine. Usual cyst(e)ine (cysteine + cystine) supply for rats from diet has been estimated to be $2.4 \mathrm{~g} / \mathrm{kg}$ diet (Reeves et al. 1993), and thus represents $211.2 \mathrm{mg} / \mathrm{kg} \mathrm{BW} /$ day. Based on several parameters including renal injuries, focal erosion in the stomach mucosa, and reticulocyte counts recorded in male rats after 4 weeks supplementation given by gavage once a day, a cysteine LOAEL equal to $500 \mathrm{mg} / \mathrm{kg} \mathrm{BW} /$ day was proposed, but no NOAEL was reported in this study (Shibui et al. 2017). From this study, we can calculate an LOAEL/ UC ratio equal to 2.4 (Table 3 ).

In humans, the mean amount of cysteine provided by the diet is $1.01 \mathrm{~g} / \mathrm{day}$ (FNB/IOM 2005), and thus represents an UC equal to $14.43 \mathrm{mg} / \mathrm{kg}$ BW/day. No NOAEL or LOAEL has been determined in humans.

\section{Glutamine and glutamate UL}

L-glutamine is the amino acid with the highest plasma concentration, while L-glutamate concentration in blood is among the lowest (Blachier et al. 2009). Both amino acids are metabolized extensively in the intestinal epithelium during their transcellular journey from the luminal content to the bloodstream (Blachier et al. 1999), serving as fuels for the enterocytes. The circulating concentration of glutamine is maintained by endogenous synthesis in the skeletal muscles, lung, and adipose tissue (Altman et al. 2016). Glutamine is a precursor for glutamate (and ammonia), that is then used as a precursor for alanine, aspartate, citrulline, and proline synthesis (Blachier et al. 2009). Glutamine is also serving for nucleotide synthesis. In addition, glutamate is a precursor, together with cysteine and glycine, for the synthesis of glutathione, and can be converted in minor amounts to $\mathrm{N}$-acetylglutamate, an allosteric regulator of carbamoyl synthetase 1, an enzyme involved notably in the urea cycle (Caldovic and Tuchman 2003). Glutamate is involved in several aspects of taste and gastrointestinal physiology (Vandenbeuch and Kinnamon 2016; Boutry et al. 2011; Kouzuki et al. 2019; Hayabuchi et al. 2020), and is well known to be an excitatory neurotransmitter in the central nervous system (Meldrum 2000), as well as a precursor for the inhibitory neurotransmitter gamma-aminobutyrate (Turner and Whittle 1983).

In rats and human, the alimentary intake of glutamine with and without glutamate has not been determined.

In rats, regarding dietary L-glutamine, based on parameters including ophthalmologic signs, histopathological analysis, urine biochemistry, and hematological parameters, after 13-week supplementation with glutamine in an ad libitum design, it was possible to determine (Table 3) a glutamine NOAEL that was estimated to be $833 \mathrm{mg} / \mathrm{kg} \mathrm{BW/}$ day in males and $946 \mathrm{mg} / \mathrm{kg} \mathrm{BW} /$ day in females (Tsubuku et al. 2004d). Regarding the LOAEL, the values have been determined to be 1654 and $1984 \mathrm{mg} / \mathrm{kg} \mathrm{BW} /$ day for male and female rats, respectively (Tsubuku et al. 2004d). Regarding L-glutamate, the NOAEL has not been determined in rats, but has been estimated in mice to be equal to 6000 and $7200 \mathrm{mg} / \mathrm{kg}$ BW/day in males and females, respectively (Anantharaman 1979).

In humans, an observed safe level of $14 \mathrm{~g}$ glutamine/day has been proposed (Shao and Hathcock 2008) that corresponds to approximately $175.0 \mathrm{mg}$ glutamine/kg BW/day.

\section{Glycine UL}

Glycine is used for protein synthesis and for the synthesis of serine and glutathione, as well as for the synthesis of creatine, purines, and heme in hemoglobin. Glycine is the most abundant amino acid in collagens (Albaugh et al. 2017).

In rats, the dietary supply of glycine from standard diet is $2.3 \mathrm{~g} / \mathrm{kg}$ diet (Reeves et al. 1993), thus representing an UC equal to $202.4 \mathrm{mg} / \mathrm{kg}$ BW/day (Table 3). Glycine was given in increasing amounts by daily gavage, and BW, food and water consumption, organ weight, hematological and histopathological parameters, daily urinary chloride excretion, as well as other urinary biochemical data, and blood biochemical parameters were determined (Shibui et al. 2013). From the data obtained, the authors have proposed for male rats a glycine NOAEL equal to $2000 \mathrm{mg} / \mathrm{kg} \mathrm{BW} / \mathrm{day}$. Then, the calculated NOAEL/UC ratio for glycine is 9.9.

In humans, the mean intake of glycine from all sources averages $3.21 \mathrm{~g} /$ day (FNB/IOM 2005), representing an UC equal to $45.86 \mathrm{mg} / \mathrm{kg} \mathrm{BW/day.} \mathrm{The} \mathrm{NOAEL} \mathrm{for} \mathrm{glycine} \mathrm{is}$ $129.0 \mathrm{mg} / \mathrm{kg} \mathrm{BW} /$ day (Inagawa et al. 2006), thus allowing to calculate an NOAEL/UC ratio equal to 2.8 .

Thus, for glycine, the NOAEL/UC ratio is 9.9 in rats, while this ratio is much lower in humans being equal to 2.8 .

\section{Proline UL}

L-proline is used for protein synthesis and is a precursor for glutamate synthesis. Proline and hydroxyproline are abundant in collagens (Albaugh et al. 2017). 
In rats, the dietary supply of proline from standard diet is $14.3 \mathrm{~g} / \mathrm{kg}$ diet (Reeves et al. 1993), corresponding to an UC equal to $1258.4 \mathrm{mg} / \mathrm{kg} \mathrm{BW} /$ day (Table 3 ). Male and female rats were fed for 90 days with diet supplemented with proline and parameters including BW, food and water intake, urine composition, hematological signs, and serum biochemistry were measured (Tada et al. 2010a). From the data obtained, the authors proposed a proline NOAEL that represents $2773 \mathrm{mg} / \mathrm{kg} \mathrm{BW} /$ day for males and $3009 \mathrm{mg} / \mathrm{kg}$ BW for females. Thus, the NOAEL /UC ratios are 2.2 and 2.4 for male and female rats, respectively. The calculated NOAEL/UC ratio for proline in rats, whatever their sex, is equal to approximately 2.3 .

In humans, the mean consumption of proline from dietary sources and supplements is $5.21 \mathrm{~g} /$ day (FNB/IOM 2005) and thus the UC is equivalent to $74.43 \mathrm{mg} / \mathrm{kg} \mathrm{BW} /$ day. No NOAEL or LOAEL has been determined in humans.

\section{Serine UL}

L-serine, in addition to being used for protein synthesis, is a precursor for synthesis of the amino acids cysteine and glycine, and for the synthesis of the sphingolipids sphingosine and sphingosine-1-phosphate, which are important regulators of several cell functions (Pyne et al. 2016). Serine can also be metabolized to pyruvate.

In rats, the serine supply from the usual standard diet is $6.7 \mathrm{~g} / \mathrm{kg}$ diet (Reeves et al. 1993), representing an UC equal to $589.6 \mathrm{mg} / \mathrm{kg} \mathrm{BW} /$ day (Table 3). Male and female rats receiving diets supplemented with increasing amounts of serine for 90 days, and for which different parameters including BW, food intake, water intake, urine analysis, serum biochemistry, hematological signs, and organ parameters were analyzed, were characterized by minor changes in the hematological signs, serum biochemistry, and organ weight. These changes were, however, not associated with pathological signs (Tada et al. 2010b). From these data, the authors proposed that a serine NOAEL equal to $2765 \mathrm{mg} / \mathrm{kg} \mathrm{BW} /$ day in males and $2905 \mathrm{mg} / \mathrm{kg}$ BW/day in females. The value found for serine NOAEL in another rat study was similar representing $3000 \mathrm{mg} / \mathrm{kg} \mathrm{BW/day} \mathrm{(Kaneko} \mathrm{et} \mathrm{al.} \mathrm{2009).} \mathrm{This}$ study was performed for 13 weeks and was based on BW, food consumption, urinalysis and hematological parameters, serum biochemistry, organ weight, and histological signs. Thus, the NOAEL/UC ratios are 4.7 and 4.9 for male and female rats, respectively (Table 3). Then, the NOAEL/UC ratio for serine in rats whatever their sex is approximately 4.8 .

In humans, the mean consumption of serine from dietary sources and supplements is $3.52 \mathrm{~g} /$ day (FNB/IOM 2005), thus representing an UC equal to $50.29 \mathrm{mg} / \mathrm{kg} \mathrm{BW} /$ day. The NOAEL for serine supplementation is $169.3 \mathrm{mg} / \mathrm{kg} \mathrm{BW} /$ day
(Miura et al. 2021). Then, the NOAEL/UC ratio for serine in volunteers is 3.4 , a value close to the one found in rats.

\section{Tyrosine UL}

L-tyrosine, in addition to being incorporated into proteins, is a precursor for the catecholamines adrenaline, noradrenaline, and dopamine (Fernstrom and Fernstrom 2007). Tyrosine is also a precursor of the pigment melanin and of the hormone thyroxine.

In rats, the supply from usual diet is $6.6 \mathrm{~g} / \mathrm{kg}$ diet (Reeves et al. 1993), thus representing an UC equal to $580.8 \mathrm{mg} / \mathrm{kg}$ BW/day (Table 3). Based on anatomical and histological considerations regarding the stomach, kidney, and liver, as well as on urine and blood biochemical parameters, recorded after supplementation of increasing doses of tyrosine given by gavage for 13 weeks in rats, the NOAEL for tyrosine was considered to be $600 \mathrm{mg} / \mathrm{kg} \mathrm{BW} /$ day in males, and $200 \mathrm{mg} /$ $\mathrm{kg} \mathrm{BW/day} \mathrm{in} \mathrm{females} \mathrm{(Shibui} \mathrm{et} \mathrm{al.} \mathrm{2016).} \mathrm{According} \mathrm{to} \mathrm{that}$ study, the NOAEL for tyrosine appears surprisingly close to the UC for males, and even lower for females. Thus, the NOAEL/UC ratios for tyrosine are 1.0 and 0.3 for male and female rats, respectively. Regarding the LOAEL, the values for male and female rats are 2000 and $600 \mathrm{mg} / \mathrm{kg} \mathrm{BW} /$ day, respectively (Shiubui et al. 2016). Thus, the LOAEL/UC ratios for tyrosine are 3.4 and 1.0 for male and female rats, respectively (Table 3 ). The reasons for increased sensitivity to the deleterious effects of tyrosine in excess, in females compared to males, remain to be determined.

In humans, the mean consumption of tyrosine from all sources is $2.79 \mathrm{~g} /$ day (FNB/IOM 2005), thus representing an UC equal to $39.86 \mathrm{mg} / \mathrm{kg}$ BW/day. No NOAEL or LOAEL has been determined in humans.

\section{Conclusion and perspectives}

The comparison between rats and humans for the NOAEL and LOAEL for each amino acid either indispensable or dispensable for which studies have been performed is presented in Tables 1 and 3. From this analysis, several conclusions can be drawn. Importantly, by simply comparing the NOAEL and LOAEL obtained in the rat model and in humans, it appears clearly as expected, that the values obtained in rats cannot be extrapolated directly to humans. This is due to the fact that the usual amino acid consumption in rats (expressed as mg amino acid per kg BW per day) is one order of magnitude higher than amino acid consumption in humans. This is related to the fact that protein consumption per $\mathrm{kg} \mathrm{BW}$ is approximately tenfold higher in rats compared to humans (Dubuisson et al. 2010; Pasiakos et al. 2015).

Thus, it appears much more relevant to compare, as done in this review, the NOAEL and LOAEL/UC ratios together 
with NOAEL and LOAEL/RQ ratios between the rat model and humans. However, due to the limited number of studies, this can be done only for the 9 amino acids arginine, glycine, histidine, serine, leucine, lysine, methionine, phenylalanine, and tryptophan. Overall, from the calculations made, it appears that for these 9 amino acids, the calculated ratios for rats and humans, although much different for several amino acids, remain for all of them within the same order of magnitude. All these data should be interpreted taking into account that the UC of indispensable amino acids originating from diet and supplement in Western countries like the USA and France are largely above the requirement.

Apart from these 9 amino acids, such comparison between rats and humans cannot be done due to a lack of data for the other 11 amino acids (isoleucine, threonine, valine, alanine, asparagine, aspartic acid, cysteine, glutamate, glutamine, proline, and tyrosine). We can only relate to the rat studies indicating that, depending on which of the 11 amino acids were tested, different NOAEL/UC ratios can be calculated ranging from 0.7 for tyrosine to 8.4 and 9.1 for arginine and threonine, respectively (Tables 1 and 3). For indispensable amino acids, different NOAEL/RQ ratios can be calculated for rats ranging from 4.8 for phenylalanine to 11.8 for threonine (Table 2). This suggests that in the rat model, some amino acids consumed above the RQ or UC are well tolerated according to the parameters measured. At the opposite, for amino acids characterized by NOAEL close to the RQ or UC, deleterious effects are likely to be observed at doses not greatly above the RQ or UC. This raises the view that a same situation may prevail in humans, as suggested by the few available data.

Using the rat model generally allows to have access to more physiological, metabolic, and functional parameters than the ones that can be obtained from clinical studies with volunteers. Then, it is tempting to propose that the ratios calculated in the rat model represent a rough but useful approximation of the corresponding ratios in humans, notably for future clinical trials with amino acids that have not been yet studied in volunteers. Second, it appears that for some amino acids (tryptophan, valine, and tyrosine, see Tables 1 and 2), the NOAEL or LOAEL measured in rats are much different based on the sex of the animals, raising the possibility that it might be also the case for humans.

Acknowledgements The authors acknowledge Universite Paris-Saclay, AgroParisTech, and INRAE for their constant support. We also thank warmly Shintaro Yoshida and Chao Huichia for constant support regarding the collection of bibliographic data.

\section{Declarations}

Conflict of interest $\mathrm{FB}, \mathrm{AB}, \mathrm{RE}, \mathrm{KS}, \mathrm{YS}$, and MK declare no conflict of interest. HM is employed by Ajinomoto Co., Inc. (Japan).
Research involving human participants and/or animals Not applicable.

Informed consent Not applicable.

Open Access This article is licensed under a Creative Commons Attribution 4.0 International License, which permits use, sharing, adaptation, distribution and reproduction in any medium or format, as long as you give appropriate credit to the original author(s) and the source, provide a link to the Creative Commons licence, and indicate if changes were made. The images or other third party material in this article are included in the article's Creative Commons licence, unless indicated otherwise in a credit line to the material. If material is not included in the article's Creative Commons licence and your intended use is not permitted by statutory regulation or exceeds the permitted use, you will need to obtain permission directly from the copyright holder. To view a copy of this licence, visit http://creativecommons.org/licenses/by/4.0/.

\section{References}

Albaugh VL, Mukherjee K, Barbul A (2017) Proline precursors and collagen synthesis: biochemical challenges of nutrient supplementation and wound healing. J Nutr 147:2011-2017

Altman BJ, Stine ZE, Dang CV (2016) From Krebs to clinic: glutamine metabolism to cancer therapy. Nat Rev Cancer 16:619-634

Anantharaman K (1979) In utero and dietary administration of monosodium L-glutamate to mice: reproductive performance and development in a multigeneration study. In: Filer LJ, Garattini S, Kare MR, Reynolds WA, Wurtman RJ (eds) Glutamic acid: advances in biochemistry and physiology. Raven Press, New York, pp p231-253

Andersen M (2015) The robustness of diagnostic tests for GH deficiency in adults. Growth Horm IGF Res 25:108-114

Andou A, Hisamatsu T, Okamoto S, Chinen H, Kamada N, Kobayashi T, Hashimoto M, Okutsu T, Shimbo K, Takeda T, Matsumoto H, Sato A, Ohtsu H, Suzuki M, Hibi R (2009) Dietary histidine ameliorates colitis by inhibition of proinflammatory cytokine production from macrophages. Gastroenterology 136:564-574

Aoki M, Ishida S, Fukuzumi H, Morishita K (2014a) A 13-week feeding toxicity study of L-threonine in rats with a recovery period of 5 weeks. Fund Toxicol Sci 2:49-62

Aoki M, Mochizuki M, Okamura T, Hatayama K, Nakamura A, Morishita K (2014b) A 4-week oral toxicity study of L-alanine in rats with a recovery period of 2 weeks. Fund Toxicol Sci 1:63-72

Baumans V (2005) Science-based assessment of animal welfare: laboratory animals. Rev Sci Tech 24:503-513

Benevenga NJ, Gahl MJ, Crenshaw TD, Finke MD (1994) Protein and amino acid requirements for maintenance and amino acid requirements for growth of laboratory rats. J Nutr 124:451-453

Blachier F, Mourtada A, Sener A, Malaisse WJ (1989) Stimulussecretion coupling of arginine-induced insulin release. Uptake of metabolized and nonmetabolized cationic amino acids by pancreatic islets. Endocrinology 124:134-141

Blachier F, Guihot-Joubrel G, Vaugelade P, Le Boucher J, Bernard F, Duée PH, Cynober L (1999) Portal hyperglutamatemia after dietary supplementation with monosodium glutamate in pigs. Digestion 60:349-357

Blachier F, Boutry C, Bos C, Tomé D (2009) Metabolism and functions of L-glutamate in the epithelial cells of the small and large intestines. Am J Clin Nutr 90:814S-821S

Blachier F, Beaumont M, Kim E (2019) Cysteine-derived hydrogen sulfide and gut health: a matter of endogenous or bacterial origin. Curr Opin Clin Nutr Metab Care 22:68-75 
Blachier F, Andriamihaja M, Blais A (2020) Sulfur-containing amino acids and lipid metabolism. J Nutr 150:2524S-2531S

Boldyrev AA, Aldini G, Derave W (2013) Physiology and pathophysiology of carnosine. Physiol Rev 93:1803-1845

Boutry C, Matsumoto H, Airinei G, Benamouzig R, Tomé D, Blachier F, Bos C (2011) Monosodium glutamate raises antral distension and plasma amino acid after a standard meal in humans. Am J Physiol 300:G137-G145

Brosnan JT, Brosnan ME (2006) The sulfur-containing amino acids: an overview. J Nutr 136:1636S-1640S

Caldovic L, Tuchman M (2003) N-acetylglutamate and its changing role through evolution. Biochem J 372:279-290

Chakravarthi S, Jessop CE, Bulleid NJ (2006) The role of glutathione in disulphide bond formation and endoplasmic-reticulum-generated oxidative stress. EMBO Rep 7:271-275

Chalvon-Demersay T, Blachier F, Tomé D, Blais A (2017) Animal models for the study of the relationships between diet and obesity: a focus on dietary protein and estrogen deficiency. Front Nutr 4:5

Chao CL, Kuo TL, Lee YT (2000) Effects of methionine-induced hyperhomocysteinemia on endothelium-dependent vasodilatation and oxidative status in healthy adults. Circulation 101:485-490

Chen W, Guo JX, Chang P (2012) The effect of taurine on cholesterol metabolism. Mol Nutr Fod Res 56:681-690

Chin K, Toue S, Kawamata Y, Watanabe A, Miwa T, Smriga M, Sakai $\mathrm{R}$ (2015) A 4-week toxicity study of methionine in male rats. Int J Toxicol 34:233-241

Cynober L, Bier DM, Kadowaki M, Morris SM Jr, Elango R, Smriga M (2016) Proposals for upper limits of safe intake for arginine and tryptophan in young adults and an upper limit of safe intake for leucine in the elderly. J Nutr 146:2652S-2654S

Deutz NE, Simbo SY, Ligthart-Melis GC, Cynober L, Smriga M, Engelen MP (2017) Tolerance to increased supplemented dietary intakes of methionine in healthy older adults. Am J Clin Nutr 2017(106):675-683

Di Buono M, Wykes LJ, Ball RO, Pencharz PB (2001) Dietary cysteine reduces the methionine requirement in men. Am $\mathrm{J}$ Clin Nutr 74:761-766

Dorato MA, Engelhardt JA (2005) The no-observed-adverse-effectlevel in drug safety evaluations: use, issues, and definition(s). Regul Toxicol Pharmacol 42:265-274

Duan Y, Duan Y, Li F, Li Y, Guo Q, Ji Y, Tan B, Li T, Yin Y (2016) Effects of supplementation with branched-chain amino acids to low protein diets on expression of genes related to lipid metabolism in skeletal muscle of growing pigs. Amino Acids 48:2131-2144

Dubuisson C, Lioret S, Touvier M, Dufour A, Calamassi-Tran G, Volatier JL, Lafay L (2010) Trends in food and nutritional intakes of French adults from 1999 to 2007: results from the INCA surveys. Br J Nutr 103:1035-1048

Ebbing M, Bleie O, Ueland PM, Nordrehaug JE, Nilsen DW, Vollset JE, Refsum H, Pedersen EK, Nygard O (2008) Mortality and cardiovascular events in patients treated with homocysteine-lowering B vitamins after coronary angiography: a randomized controlled trial. JAMA 300:795-804

Elango R, Rasmussen B, Madden K (2016) Safety and tolerability of leucine supplementation in elderly men. J Nutr 146:2630S-2634S

Etchegaray JP, Mostoslavsky R (2016) Interplay between metabolism and epigenetics: a nuclear adaptation to environmental changes. Mol Cell 62:695-711

Fernstrom JD, Fernstrom MH (2007) Tyrosine, phenylalanine, and cathecholamine synthesis and function in the brain. J Nutr 137:1539S-1547S

Food and Nutrition Board (FNB), Institute of Medicine (IOM) (2005) Dietary reference intake for energy, carbohydrate, fiber, fat, fatty acids, cholesterol, protein, and amino acids. The National Academies Press, Washington DC

Fürst P, Stehle P (2004) What are the essential elements needed for the determination of amino acid requirements in humans? J Nutr 134:1558S-1565S

Gheller ME, Vermeylen F, Handzlik MK, Gheller BJ, Ender E, Metallo C, Aydemir TB, Smriga M, Thalacker-Mercer E (2020) Tolerance to graded dosage of histidine supplementation in healty human adults. Am J Clin Nutr 112:1358-1367

Gietzen DW, Rogers QR (2006) Nutritional homeostasis and indispensable amino acid sensing: a new solution to an old puzzle. Trends Neurosci 29:91-99

Harper AE, Benevenga NJ, Wohlhueter RM (1970) Effects of ingestion of disproportionate amounts of amino acids. Physiol Rev 50:428-558

Hayabuchi H, Morita R, Ohta M, Nanri A, Matsumoto H, Fujitani S, Yoshida S, Ito S, Sakima A, Takase H, Kusaka M, Tsuchihashi $\mathrm{T}$ (2020) Validation of preferred salt concentration in soup based on randomized blinded experiment in multiple regions in Japan influence of umami (L-glutamate) on saltness and palatability of low-salt solutions. Hypertens Res 43:525-533

Hayamizu K, Oshima I, Fukuda Z, Kuramochi Y, Nagai Y, Izumo N, Nakano M (2019) Safety assessment of lysine oral intake: a systematic review. Amino Acids 51:647-659

Hiratsuka C, Fukuwatari T, Sano M, Saito K, Sasaki S, Shibata K (2013) Supplementing healthy women with up to $5.0 \mathrm{~g} / \mathrm{d}$ of L-tryptophan has no adverse effects. J Nutr 143:859-866

Ikesaki S, Nishikawa A, Furukawa F, Imazawa T, Enami T, Mitsui M, Takahashi M (1994) 13-week subchronic toxicity study of L-histidine monohydrochloride in F344 rats. Eisei Shikenjo Hokoku (bull Natl Ins Health Sci) 112:57-63

Illner AK, Nötlings U, Wagner K, Ward H, Boeing H (2010) The assessment of individual usual food intake in large-scale prospective studies. Ann Nutr Metab 56:99-105

Inagawa K, Kawai N, Ono K, Sukegawa E, Tsubuku S (2006) Assessment of acute adverse events of glycine ingestion at a high dose in human volunteers. Seikatsu Eisei J Urban Living Health Assoc 50:27-32

Kaluzna-Czaplinska J, Gatarek P, Chirumbolo S, Chartrand MS, Bjorklund G (2019) How important is tryptophan in human health. Crit Rev Food Sci Nutr 59:72-88

Kaneko I, Han L, Liu T, Li J, Zhao Y, Li C, Yi Y, Liang A, Hayamizu K (2009) A 13-week subchronic oral toxicity study of L-serine in rats. Food Chem Toxicol 47:2356-2360

Kemp M, Go YM, Jones DP (2008) Nonequilibrium thermodynamics of thiol/disulfide redox systems: a perspective on redox systems biology. Free Radic Biol Med 44:921-937

Kennedy E, Meyers L (2005) Dietary reference intakes: development and uses for assessment of micronutrient status of women: a global perspective. Am J Clin Nutr 81:1194S-1197S

Kouzuki M, Taniguchi M, Suzuki T, Nagano M, Nakamura S, Katsumata Y, Matsumoto H, Urakami K (2019) Effect of monosodium L-glutamate (umami substance) on cognitive function in people with dementia. Eur J Clin Nutr 73:266-275

Liu X, Beaumont M, Walker F, Chaumontet C, Andriamihaja M, Matsumoto H, Khodorova N, Lan A, Gaudichon C, Benamouzig R, Tomé D, Davila AM, Marie JC, Blachier F (2013) Beneficial effects of an amino acid mixture on colonic mucosal healing in rats. Inflamm Bowel Dis 19:2895-2905

Liu X, Blouin JM, Santacruz A, Lan A, Andriamihaja M, Wilkanowicz S, Benetti PH, Tomé D, Sanz Y, Blachier F, Davila AM (2014) High-protein diet modifies colonic microbiota and luminal environment but not colonocyte metabolism in the rat model: the increased luminal bulk connection. Am J Physiol 307:G459-G470

Longo N, Frigeni M, Pasquali M (2016) Carnitine transport and fatty acid oxidation. Biochim Biophys Acta 1863:2422-2435 
Malmezat T, Breuillé D, Capitan P, Mirand PP, Obled C (2000) Glutathione turover is increased during the acute phase of sepsis in rats. J Nutr 130:1239-1246

Mani S, Li H, Untereiner A, Wu L, Yang G, Austin RC, Dickout JG, Lhotak S, Meng QH, Wang R (2013) Decreased endogenous production of hydrogen sulfide accelerates atherosclerosis. Circulation 127:2523-2534

Martin A, Touvier M, Volatier JL (2004) The basis for setting the upper range of adequate intake for regulation of macronutriment intakes, especially amino acids. J Nutr 134:1625S-1629S

Martinez-Arnau FM, Fonfria-Vivas R, Buiges C, Castillo Y, Molona P, Hoogland AJ, van Doesburg F, Pruimboom L, Fernandez-Garrido J, Cauli O (2020) Effects of leucine administration in sarcopenia: a randomized and placebo-controlled clinical trial. Nutrients 12(4):932

Matsumoto H, Akita K, Sakai R, Shimomura Y (2010) Analysis of branched-chain alpha-keto acid dehydrogenase complex activity in rat tissues using alpha-keto $\left(1-{ }^{13} \mathrm{C}\right)$ isocaproate as substrate. Anal Biochem 399:1-6

Matsumoto T, Nakamura K, Matsumoto H, Sakai R, Kuwahara T, Kadota Y, Kitaura Y, Sato J, Shimomura Y (2014) Bolus ingestion of individual branched-chain amino acids alters plasma amino acid profiles in young healthy men. Springerplus 3:35

Mawatari K, Katsumata T, Uematsu M, Katsumata T, Yoshida J, Smriga M, Kimura T (2004) Prolonged oral treatment with an essential amino acid L-leucine does not affect female reproductive function and embryo-fetal development in rats. Food Chem Toxicol 42:1505-1511

McNeal CJ, Meininger CJ, Wilborn CD, Tekwe CD, Wu G (2018) Safety of dietary supplementation with arginine in adult humans. Amino Acids 50:1215-1229

Meldrum BS (2000) Glutamate as a neurotransmitter in the brain: review of physiology and pathology. J Nutr 130:1007S-1015S

Miura N, Matsumoto H, Cynober L, Stover PJ, Elango R, Kadowaki M, Smriga BDM, M, (2021) Subchronic tolerance trials of graded oral supplementation with phenylalanine or serine in healthy adults. Nutrients 13:1976

Moehn S, Pencharz PB, Ball RO (2012) Lessons learned regarding symptoms of tryptophan deficiency and excess from animal requirement studies. J Nutr 142:2231S-2235S

Munasinghe LL, Robinson JL, Harding SV, Brunton JA, Bertolo RF (2017) Protein synthesis in mucin-producing tissues is conserved when dietary threonine is limiting in piglets. J Nutr 147:202-210

Napoli C, Ignarro LJ (2009) Nitric oxide and pathogenic mechanisms involved in the development of vascular diseases. Arch Pharm Res 32:1103-1108

Pasiakos SM, Agarwal S, Lieberman HR, Fulgoni VL (2015) Sources and amounts of animal, dairy, and plant protein intake of US adults in 2007-2010. Nutrients 7:7058-7069

Pegg AE (2016) Functions of polyamines in mammals. J Biol Chem 291:14904-14912

Pencharz PB, Elango R, Ball RO (2012) Determination of the tolerable upper uptake level of leucine in adult men. J Nutr 142:2220S-2224S

Pizzo F, Benfenati E (2016) In silico models for repeated-dose toxicity (RDT): prediction of the no observed adverse effect level (NOAEL) and lowest observed adverse effect level (LOAEL) for drugs. Methodes Mol Biol 1425:163-176

Pyne S, Adams DR, Pyne NJ (2016) Sphingosine 1-phosphate and sphingosine kinases in health and disease: recent advances. Prog Lipid Res 62:93-106

Reeds PJ (2000) Dispensable and indispensable amino acids for humans. J Nutr 130:1835S-1840S

Reeves PG, Nielsen FH, Fahey GC Jr (1993) AIN-93 purified diet for laboratory rodents: final report of the American institute of nutrition ad hoc writing committee on the reformulation of the AIN-76A rodent diet. J Nutr 123:1939-1951

Rémond D, Buffière C, Pouyet C, Papet I, Dardevet D, Savary-Auzeloux I, Williamson G, Faure M, Breuillé D (2011) Cysteine fluxes across the portal-drained viscera of enterally fed minipigs: effect of an acute intestinal inflammation. Amino Acids 40:543-552

Schwarcz R, Stone TW (2017) The kynurenine pathway and the brain: challenges, controversies and promises. Neuropharmacol 112:237-247

Shao A, Hathcock JN (2008) Risk assessment for the amino acids taurine, L-glutamine and L-arginine. Regul Toxicol Pharmacol 50:376-399

Shibui Y, Miwa T, Yamashita M, Chin K, Kodama T (2013) A 4-week repeated dose toxicity study of glycine in rats by gavage administration. J Toxicol Pathol 26:405-412

Shibui Y, Miwa T, Kodama T, Gonsho A (2014) 28-day dietary toxicity study of L-phenylalanine in rats. Fund Toxicol Sci 1:29-38

Shibui Y, Manabe Y, Kodama T, Gonsho A (2016) 13-week repeated dose toxicity study of L-tyrosine in rats by daily oral administration. Food Chem Toxicol 87:55-64

Shibui Y, Sakai R, Manabe Y, Masuyama T (2017) Comparison of L-cysteine and D-cysteine toxicity in 4-week repeated-dose toxicity studies of rats receiving daily oral administration. J Toxicol Pathol 30:217-229

Shibui Y, Matsumoto H, Masuzawa Y, Ohishi T, Fukawatari T, Shibata K, Sakai R (2018) Thirteen week toxicity study of dietary L-tryptophan in rats with a recovery period of 5 weeks. J Appl Toxicol 38:552-563

Siddiqui S, Zainal H, Noor Harun S, Sheikh Ghadzi SM (2019) Dietary assessment of pre-diabetic patients by using food frequency questionnaire. A systematic review of study quality, study outcome, study questionnaire and their relative validity and reliability. Clin Nutr ESPEN 29:213-223

Strumia E, Pelliccia F, D’Ambroso G (2012) Creatine phosphate: pharmacological and clinical perspectives. Adv Ther 29:99-123

Tada Y, Yano N, Takahashi H, Yusawa K, Ando H, Kubo Y, Nagasawa A, Uehara S, Ogata A, Nakae D (2008) Toxic effects of L-aspartic acid at high dose levels on kidneys and salivary glands in Fischer 344 rats detected in a 90-day feeding study. Food Chem Toxicol 46:2789-2795

Tada Y, Nano N, Takahashi H, Yuzuma K, Ando H, Kubo Y, Nagasawa A, Ohashi N, Ogata A, Nakae D (2010a) Toxicological evaluation of L-proline in a 90-day feeding study with Fischer 344 rats. Regul Toxicol Pharmacol 58:114-120

Tada Y, Yano N, Takahashi H, Yuzawa K, Ando H, Kubo Y, Nagasawa A, Chin K, Kawamata Y, Sakai R, Ohashi N, Ogata A, Nakae D (2010b) A-90-day feeding toxicity study of L-serine in male and female Fischer 344 rats. J Toxicol Pathol 23:39-47

Tsubuku S, Hatayama K, Katsumata T, Nishimura N, Mawatari K, Smriga M, Kimura T (2004a) Thirteen-week oral toxicity study of branched-chain amino acids in rats. Int J Toxicol 23:119-126

Tsubuku S, Mochizuki M, Mawatari K, Smriga M, Kimura T (2004b) Thirteen-week oral toxicity study of L-lysine hydrochloride in rats. Int J Toxicol 23:113-118

Tsubuku S, Hatayama K, Mawatari K, Smriga M, Kimura T (2004c) Thirteen-week oral toxicity study of L-arginine in rats. Int J Toxicol 23:101-105

Tsubuku S, Hatayama K, Mawatari K, Smriga M, Kimura T (2004d) Thirteen-week oral toxicity study of L-glutamine in rats. Int J Toxicol 23:107-112

Turner AJ, Whittle SR (1983) Biochemical dissection of the gammaaminobutyrate synapse. Biochem J 209:29-41

Van der Veen JN, Kenelly JP, Wan S, Vance JE, Vance DE, Jacobs RL (2017) The critical role of phosphatidylcholine and phosphatidylethanolamine metabolism in health and disease. Biochim Biophys Acta 1859:1558-1572 
Vandenbeuch A, Kinnamon SC (2016) Glutamate: tastant and neuromodulator in taste buds. Adv Nutr 7:823S-827S

Wandrag L, Brett SJ, Frost G, Hickson M (2015) Impact of supplementation with amino acids or their metabolites on muscle wasting in patients with critical illness or other muscle wasting illness: a systematic review. J Hum Nutr Diet 28:313-330

Windmueller HG, Spaeth AE (1976) Metabolism of absorbed aspartate, asparagine, and arginine by rat small intestine in vivo. Arch Biochem Biophys 175:670-676

Yokohira M, Hosokawa K, Yamakawa K, Hashimoto N, Suzuki S, Matsuda Y, Saoo K, Kuno T, Imaida K (2008) A 90-day toxicity study of L-asparagine, a food additive, in F344 rats. Food Chem Toxicol 46:2568-2572
Zylberstein DE, Bengtsson C, Bjorkelund C, Landaas S, Sundh V, Thelle D, Lissner L (2004) Serum homocysteine in relation to mortality and morbidity from coronary heart disease: a 24 -year follow-up of the population study of women in Gothenberg. Circulation 109:601-606

Publisher's Note Springer Nature remains neutral with regard to jurisdictional claims in published maps and institutional affiliations. 